\title{
PENGARUH HARGA, PROMOSI DAN KUALITAS PELAYANAN TERHADAP KEPUASAN KONSUMEN DI CAFÉ KUPI DATU BANJARBARU
}

\author{
Susiladewi \\ E - mail : dewisusila401@yahoo.com
}

Fakultas Ekonomi Universitas Islam Kalimantan MAB Banjarmasin

\begin{abstract}
This study aims to determine and analyze the effect of Price, Promotion and Quality of services provided by Café Kupi Datu on customer satisfaction both partially and simultaneously. This research is quantitative research. The research design uses formal research procedures that contain clear definitions of research objectives and information needs. To answer and achieve the research objectives, regression analysis will be used. Regression analysis is a statistical method that aims to see the direction of the relationship and the magnitude of influence between 2 or more variables in a linear form. Therefore, the research model in this study is $Y=\alpha+\beta X+\mathrm{e}$. The results showed that, it turns out that the independent variable that has the largest beta is the Price variable (X1) that is equal to 0.659 or by $65.9 \%$. Therefore it can be said that the variable that has the greatest effect on customer satisfaction Café Kupi Datu is the variable X1 (Price) with a standard regression coefficient of 0.659 . The results of the first hypothesis (H1) are the decision to reject $\mathrm{H} 0$ and accept $\mathrm{Ha}$, which means the $\mathrm{F}$ test of the regression equation obtained from this study shows the results that, together with the three variables price, promotion and quality of service affect the consumer satisfaction at Café Kupi Datu .
\end{abstract}

Keywords: Price, Promotion, Service Quality, Satisfaction. 


\section{PENDAHULUAN}

Salah satu tindakan untuk memuaskan konsumen adalah dengan cara memberikan pelayanan kepada konsumen dengan sebaik-baiknya. Kenyataan ini bisa dilihat, bahwa ada beberapa hal yang dapat memberikan kepuasan pelanggan yaitu nilai total pelanggan yag terdiri dari nilai produk, nilai pelayanan, nilai personal, nilai image atau citra, dan biaya total pelanggan yang terdiri dari biaya moneter, biaya waktu, biaya tenaga, dan biaya pikiran (Kotler, 2000:50). Dengan adanya kualitas pelayanan yang baik di dalam suatu perusahaan, akan menciptakan kepuasan bagi para konsumennya. Setelah konsumen merasa puas dengan produk atau jasa yang diterimanya, konsumen akan membandingkan pelayanan yang diberikan. Apabila konsumen merasa benar-benar puas, mereka akan membeli ulang serta memberi rekomendasi kepada orang lain untuk membeli di tempat yang sama. Oleh karena itu perusahaan harus memulai memikirkan pentingnya pelayanan pelanggan secara lebih matang melaui kualitas pelayanan, karena kini semakin disadari bahwa pelayanan (kepuasan pelanggan) merupakan aspek vital dalam rangka bertahan dalam bisnis dan memenangkan persaingan (Tjiptono, 2004:145).

Menghadapi semakin ketatnya persaingan bisnis khususnya dibidang kuliner yakni kopi, maka untuk dapat memenangkan persaingan sekaligus agar dapat bertahan Café Datu yang berada di wilayah Banjarbaru perlu melakukan berbagai strategi dalam menjalankan bisnisnya. Selain harga yang menjadi pertimbangan ada beberapa pertimbangan lain yang tak kalah penting antara lain yaitu kualitas pelayanan, dan fasilitas yang diberikan. Pelayanan adalah faktor penting dan utama dalam sebuah usaha dibidang kuliner, di mana para pelanggan akan merasa puas apabila mereka memperoleh pelayanan yang baik akan tetapi para pelanggan akan pergi apabila pelayanan yang diberikan tidaklah memuaskan. 
Selain itu dengan didukung fasilitas serta kualitas yang memenuhi syarat serta harga yang terjangkau, maka tentulah hal tersebut akan membuat konsumen merasa terpuaskan. Dengan adanya integrasi unsur-unsur tersebut tentu akan menjadi kunci keberhasilan perusahaan jasa untuk meningkatkan informasi, membangun kepuasan pelanggan melalui kualitas pelayanan.

Menghadapi semakin ketatnya persaingan bisnis khususnya dibidang kuliner, maka untuk dapat memenangkan persaingan sekaligus agar dapat bertahan Kopi Datu perlu melakukan berbagai strategi dalam menjalankan bisnisnya. Selain bentuk fisik yang menjadi pertimbangan ada beberapa pertimbangan lain yang tak kalah penting antara lain yaitu harga yang ditawarkan. Akhir-akhir ini Café Kupi Datu menunjukan penurunan dalam hal memberikan pelayanan kepada konsumen. Penurunan ini disebabkan oleh berbagai faktor internal dan eksternal, seperti kesadaran karyawan dalam memberikan pelayanan yang optimal kepada konsumen dan Promosi yang dilakukan masih sangat kurang serta harga yang terbilang tinggi. Pada umumnya Café Kupi Datu menghadapi tantangan yang lebih besar dibandingkan dengan café-café kopi yang lain dalam pengelolaannya, karena disatu sisi segmennya terbatas sedangkan dari tuntutan fasilitas dan pelayanan biasanya lebih tinggi sehingga jika pelayanan, promosi dan harga pada Café Kupi Datu ini tidak dikelola dengan baik maka eksistensinya pun sulit untuk dipertahankan, yang berarti tujuan profitabilitas tidak dapat tercapai.

Harga merupakan satu-satunya unsur marketing mix yang menghasilkan penerimaan penjualan, sedangkan unsur lainnya hanya unsur biaya saja. Walaupun penetapan harga merupakan persoalan penting, masih banyak perusahaan yang kurang sempurna dalam menangani permasalahan penetapan harga tersebut. Karena menghasilkan penerimaan penjualan, maka harga mempengaruhi tingkat penjualan, tingkat keuntungan, serta share pasar yang dapat dicapai oleh perusahaan. Kotler, 
(2008) mengemukakan bahwa harga merupakan satu-satunya elemen bauran pemasaran yang menghasilkan pendapatan, elemen-elemen lainnya menimbulkan biaya. Harga juga merupakan salah satu elemen bauran pemasaran yang paling fleksibel. Harga dapat diubah dengan cepat, tidak seperti ciri khas (feature) produk dan perjanjian distribusi. Pada saat yang sama, penetapan dan persaingan harga juga merupakan masalah nomor satu yang dihadapi perusahaan.

Strategi promosi merupakan kegiatan bauran pemasaran yang terakhir. Dalam menghadapi persaingan perusahaan memerlukan strategi promosi untuk dapat memperkenalkan produknya dan menarik perhatian konsumen. Promosi sangat penting untuk keberhasilan pemasaran. Menurut Freddy Rangkuti (2002:1), Kegiatan promosi, bagi banyak perusahaan, merupakan kegiatan investasi yang sangat kritis melalui kegiatan pemasaran. Tanpa promosi maka konsumen akan sulit untuk mengetahui produk yang dijual oleh perusahaan. Strategi pelaksanaan promosi merupakan langkah-langkah yang secara berurutan dari awal sampai akhir dalam proses mempromosikan suatu produk, yaitu melalui periklanan yang kemudian diikuti dengan kegiatan promosi lainnya, diantaranya personal selling, promosi penjualan, dan publisitas. Promosi dipandang sebagai kegiatan komunikasi pembeli dan penjual dan merupakan kegiatan yang membantu dalam pengambilan keputusan dibidang pemasaran serta mengarahkan dan menyadarkan semua pihak untuk berbuat lebih baik. Swastha (2001) Promosi yang tepat akan meningkatkan minat beli konsumen. Demikian pula penetapan harga yang sesuai dengan segmentasi dan sasaran pasar yang dituju. Para pelaku usaha perlu melakukan aktifitas promosi yang tepat dan penetapan harga yang sesuai, sehingga mampu menarik minat beli konsumen. 


\section{TINJAUAN PUSTAKA}

\section{Pengertian pemasaran}

Kotler dan Armstrong (2014:27) menyatakan the process by which companies create value for customers and build strong customer relationships in order to capture value from customer in return. Definisi tersebut mengartikan bahwa pemasaran adalah proses dimana perusahaan menciptakan nilai bagi pelanggan dan membangun hubungan yang kuat dengan pelanggan, dengan tujuan menangkap nilai dari pelanggan sebagai imbalannya.

Pemasaran adalah serangkaian aktivitas yang dilakukan perusahaan untuk menstimulasi permintaan atas produ atau jasanya dan memastikan bahwa produk dijual dan disampaikan kepada para pelanggan (venkatesh \& Penaloza, 2006). Maka kegiatan pemasaran dapat diartikan sebagai kegiatan manusia yang berlangsung dalam kaitannya dengan pasar. Jadi dapat disimpulkan bahwa pemasaran sebuah proses social dan manajerial yang melibatkan kepentingan-kepentingan baik individu atau kelompok dalam memenuhi kebutuhan dan keinginan melalui pertukaran barang ataupun jasa kepada pelanggan dari produsen. Menurut Basu dan Hani (2004 : 4) pemasaran yang meliputi dari proses kegitan perencanaan dalam pengelolaan barang dan jasa, penetapan banderol harga dari barang dan jasa tersebut hingga proses promosi maupun pendistribusiannya yang keseluruhannya memiliki tujuan untuk memenuhi kebutuhan maupun memperoleh keuntungan dari proses pemasaran tersebut.

Tujuan utama pemasaran yaitu untuk melayani kosumen dengan menndapatkan sejumah laba, atau dapat diartikan sebagai perbandingan antara penghasilan dengan biaya yang layak.Ini berbeda dengan konsep penjualan yang menitikberatkan pada keinginan perusahaan.Seperti halnya dengan pendekatan konsep pemasaran 
menghendaki agar manjemen menetukan keinginan konsumen terlebih dahulu setelah itu baru melakukan bagaimana caranya memuaskan konsumen.

\section{Konsep Pemasaran}

Pemasaran tidak hanya menjual barang atau jasa sesuai dengan keinginan dan kebutuhan pasar saja, tetapi juga fungsi sebagai penarik pelanggan. Penggunaan konsep pemasaran bagi sebuah perusahaan dapat menunjang berhasilnya bisnis yang dilakukan. Sebagai falsafah bisnis, konsep pemasaran disusun dengan memasukkan tiga elemen pokok, yaitu :

a. Seluruh perencanaan dan keinginan perusahaan harus berorientasi pada konsumen atau pasar.

b. Volume penjualan yang bisa menguntungkan bagi perusahaan harus menjadi tujuan pokok perusahaan.

c. Suatu kegiatan pemasaran dalam perusahaan hendaknya dikoordinasi dan diintegrasikan secara organisasi.

\section{Marketing Mix}

Upaya pemenuhan kepuasan pelanggan melalui penciptaan, penyerahan, dan pengkomunikasian nilai pelanggan kepada pasar sasaran yang terpilih merupakan kunci utama konsep pemasaran. Di dalam konsep pemasaran holistik mengakui bahwa "segala sesuatu bisa terjadi" pada pemasaran dan bahwa pemasaran perspektif yang luas dan terpadu sering dibutuhkan. Empat komponen dari pemasaran holistik adalah pemasaran hubungan, pemasaran terpadu, pemasaran internal, dan pemasaran yang bertanggung jawab sosial (Kotler dan Keller, 2008). Marketing mix merupakan bagian dari pemasaran terpadu. Jika dilihat dari segi bauran pemasaran, marketing mix merupakan perangkat alat pemasaran yang digunakan perusahaan untuk mengejar tujuan perusahaannya melalui pemenuhan nilai bagi konsumen. 
McCharthy mengklasifikasikan marketing mix menjadi 4 kelompok besar (4 P), yaitu : produk (product), harga (price), sistem distribusi (place), dan promosi (promotion) (Kotler dan Keller, 2008). Berdasarkan dari pendapat McCharthy (Kotler dan Keller, 2008) tersebut maka dapat dijelaskan sebagai berikut:

a. Product (Produk). Produk adalah segala sesuatu yang dihasilkan produsen dan ditawarkan ke pasar untuk memuaskan keinginan dan kebutuhan konsumen. Agar produk dapat berhasil dipasaran, maka perlu adanya bauran produk (produk mix). Produk mix meliputi perencanaan dan pengendalian produk serta keputusankeputusan tentang pembelian produk.

b. Price (Harga). Harga bertujuan mengkomunikasikan posisi nilai yang dimaksudkan perusahaan tersebut kepada pasar tentang produk dan merek. Dalam penentuan harga, perusahaan harus memperhatikan berbagi faktor yang menyangkut biaya produksi. Harga yang harus ditawarkan perusahaan diharapkan terjangkau. Dalam penerapan marketing mix perusahaan hendaknya harus memperhatikan hal-hal sebagai berikut:

1) Marketing mix haruslah seimbang

2) Marketing mix tidak boleh bersifat statis, maksudnya marketing mix harus dilakukan secara kreatif

3) Marketing mix tidak boleh meniru

4) Marketing mix harus mempunyai tujuan jangka panjang

5) Dalam penerapannya harus didasarkan pada pengalaman

c. Place (Sistem Distribusi). Sistem distribusi dapat juga disebut dengan saluran pemasaran. Sistem distribusi adalah beberapa organisasi yang saling bergantung dan terlibat dalam mengupayakan agar produk atau jasa dapat sampai ketangan konsumen sehingga produk dapat digunakan atau dikonsumsi.

51

Jurnal Komunikasi Bisnis dan Manajemen

Vol.7 No.2 Juli 2020 
d. Promotion (Promosi). Kegiatan yang dilakukan perusahaan dalam memperkenalkan produknya pada masyarakat. Dalam melakukan promosi, perusahaan berusaha menonjolkan kelebihan dan keistimewaan produknya dengan tujuaan membujuk konsumen agar membeli produk tersebut.

\section{Harga}

Harga produk atau jasa yang dipasarkan merupakan faktor yang sangat penting. Harga sangat menentukan atau mempengaruhi permintaan pasar. Di dalam persaingan usaha yang semakin ketat sekarang ini dan semakin banyaknya usaha-usaha baru yang bergerak di bidang yang sama atau hampir sama, menuntut perusahaan dapat menentukan harga terhadap produk atau jasa yang mereka jual dengan tepat. Persaingan harga sangat mempengaruhi bertahan atau tidaknya suatu perusahaan menghadapi para pesaingnya. Menurut Stanton (2004:306) harga pasar sebuah produk mempengaruhi upah, sewa, bunga, dan laba. Artinya, harga produk mempengaruhi biaya faktor-faktor produksi (tenaga kerja, tanah, modal, dan kewiraswastaan. Sehingga definisi harga adalah alat pengukur dasar sebuah sistem ekonomi karena harga mempengaruhi alokasi faktor-faktor produksi. Dan harga juga dapat didefinisikan sebagai jumlah uang yang dibutuhkan untuk memperoleh beberapa kombinasi sebuah produk dan pelayanan yang menyertainya. Dalam menghadapi persaingan, perusahaan perlu lebih bijaksana dalam menentukan harga produknya. Banyak hal-hal yang harus dipertimbangkan oleh pengusaha sebelum menetapkan harga suatu produk.

Menurut Kotler (2007), perusahaan-perusahaan melakukan penetapan harga dengan berbagai cara. Di perusahaan-perusahaan kecil, harga ditetapkan oleh pimpinan yang tertinggi. Banyak konsumen menggunakan harga sebagai indikator mutu produk atau jasa yang akan dibelinya. Harga merupakan salah satu faktor penentu konsumen dalam menentukan suatu keputusan pembelian terhadap suatu 
produk maupun jasa. Apalagi apabila produk atau jasa yang akan dibeli tersebut merupakan kebutuhan sehari-hari seperti makanan, minuman dan kebutuhan pokok lainnya, konsumen akan sangat memperhatikan harganya. Pengusaha perlu untuk memperhatikan hal ini, karena dalam persaingan usaha, harga yang ditawarkan oleh pesaing bisa lebih rendah dengan kualitas yang sama atau bahkan dengan kualitas yang lebih baik. Sehingga dalam penentuan harga produk atau jasa yang dijual,baik perusahaan besar maupun usaha kecil sekalipun harus memperhatikan konsumen dan para pesaingnya.

Konsumen dalam melakukan pembelian, faktor harga merupakan faktor yang lebih dulu diperhatikan, kemudian disesuaikan dengan kemampuannya sendiri. Harga dapat diklasifikasikan menjadi tiga,yaitu: mahal, sedang, dan murah. Sebagian konsumen yang berpendapatan menengah menganggap bahwa harga yang ditawarkan mahal, namun konsumen yang berpendapatan tinggi beranggapan bahwa harga produk tersebut murah. Tingkat persaingan yang tinggi antara perusahaan atau usahausaha sejenis, membuat konsumen sensitif terhadap harga. Apabila harga dinaikkan, konsumen cenderung untuk berpindah ke perusahaan lain. Hal ini berartibahwa faktor harga merupakan faktor yang sangat menentukan dalam keputusan pembelian produk (Tedjakusuma, Hartini, dan Muryani, 2001).

\section{Promosi}

Promosi merupakan salah satu bagian dari rangkaian kegiatan pemasaran suatu barang. Promosi adalah suatu kegiatan bidang marketing yang merupakan komunikasi yang dilaksanakan perusahaan kepada pembeli atau konsumen yang memuat pemberitaan, membujuk, dan mempengaruhi segala sesuatu mengenai barang maupun jasa yang dihasilkan untuk konsumen, segala kegiatan itu bertujuan untuk meningkatkan volumen penjualan dengan menarik minat konsumen dalam mengambil 
keputusan membeli di perusahaan tersebut. Untuk memperjelas tentang pengertian promosi, berikut ini beberapa definisi tentang promosi.

Menurut Tjiptono (2000:219) “Pada hakikatnya promosi adalah suatu bentuk komunikasi pemasaran". Adapun yang dimaksud dengan komunikasi pemasaran adalah aktivitas pemasaran yang berusaha menyebarkan informasi, mempengaruhi/membujuk, dan/atau mengingatkan pasar sasaran atas perusahaan dan produknya agar bersedia menerima, membeli, dan loyal pada produk yang ditawarkan perusahaan yang bersangkutan.

Menurut Kotler dan Amstrong (2001), Promosi merupakan sarana bagi perusahaan, berupa suatu kegiatan dengan tujuan menciptakan komunikasi yang terarah antara produsen dan konsumen". Dari definisi tersebut dapat disimpulkan bahwa perusahaan harus berhati-hati dalam memadukan alat-alat promosi utama tersebut periklanan, promosi penjualan, hubungan masyarakat, dan pemasaran langsung Perusahaan agar dapat menghasilkan bauran promosi yang terkoordinasi.

Menurut Umar Farouk (2010), “didalam komunikasi promosi merupakan sesuatu yang mengundang minat dan menyajikan informasi agar konsumen terdorong untuk membeli". Berdasarkan teori tersebut, maka dapat disimpulkan bahwa promosi ada hubungannya dengan komunikasi, dengan proses komunikasi dapat mengundang minat dan dapat memberikan informasi yang disampaikan konsumen yang tujuannya untuk konsumen dapat terdorong untuk membeli.

\section{Kualitas Pelayanan}

Kualitas merupakan kondisi dinamis yang berhubungan dengan produk, jasa, manusia, proses dan lingkungan yang memenuhi atau melebihi harapan (Tjiptono, 2004). Sehingga definisi kualitas pelayanan dapat diartikan sebagai upaya pemenuhan kebutuhan dan keinginan konsumen serta ketepatan penyampaiannya dalam mengimbangi harapan konsumen (Tjiptono, 2004). Lovelock, Patersson and Walker 
(2005) dalam Tjiptono dan Chandra (2005) mengelompokkan proses jasa berdasarkan dua dimensi utama yaitu penerima jasa dan sifat tindakan jasa. Terdapat empat tipe jasa berdasarkan kriteria tersebut, yaitu:

\section{1) People-Processing Service}

Dalam tipe ini, tangible actions ditujukan pada tubuh manusia, contohnya jasa transportasi, tukang pijat, salon kecantikan dan operasi bedah. Pelanggan harus hadir secara fisik, karena pelanggan menjadi bagian dari proses produksi yang berlangsung secara simultan dengan proses konsumsi. Dalam konteks ini, pelanggan harus mendatangi tempat jasa disediakan atau sebaliknya penyedia jasa harus mendatangi lokasi pelanggan.

2) Possession-Processing Services

Tipe ini berkenaan dengan melakukan sesuatu atas produk fisik untuk meningkatkan nilainya bagi pelanggan. Contohnya, reparasi mobil, mengantarkan pengiriman paket, merawat dan membersihkan kantor. Dalam hal ini, objek kepemilikan yang membutuhkan pemrosesan jasa harus ada, sementara pelanggan tidak harus hadir secara fisik dalam proses penyampaiannya jasa.

\section{3) Mental-Stimulus Processing Services}

Tipe ini berupa intangibles actions yang ditujukan pada benak atau pikiran orang, misalnya jasa siaran televisi, event olahraga, pentas musik, teater dan jasa pendidikan. Dalam kasus ini, pelanggan harus hadir secara mental, namun bisa berlokasi di fasilitas jasa spesifik maupun di lokasi jarak jauh yang terhubung dengan jaringan telekomunikasi.

4) Information Processing Services

Tipe ini berupa intangibles actions yang ditujukan pada intangible assets dan terdiri dari atas pengumpulan, interpretasi dan pengiriman data untuk menciptakan nilai tambah. Contohnya, jasa perbankan, jasa konsultasi, akuntansi dan pendidikan. 
Keterlibatan pelanggan dalam produksi jasa semacam ini bisa ditekan hingga minimum, misalnya dengan menggunakan teknologi telekomunikasi.

Kualitas pelayanan (service quality) dapat diukur dengan menggunakan lima dimensi. Kelima dimensi tersebut menurut Parasuraman, Zeithaml dan Berry dalam Tjiptono (2005) adalah:

1) Bukti langsung (tangibles), meliputi fasilitas fisik, perlengkapan, pegawai dan sarana komunikasi.

2) Reliabilitas (reliability), kemampuan untuk memberikan pelayanan yang dijanjikan dengan segera, akurat dan memuaskan.

3) Daya tanggap (responsiveness), yaitu keinginan untuk membantu para konsumen dan memberikan pelayan sebaik mungkin.

4) Jaminan / keyakinan (assurance), yaitu pengetahuan dan kesopansantunan para pegawai perusahaan serta kemampuan menumbuhkan rasa percaya para konsumennya kepada perusahaan.

5) Empati (empathy), meliputi kemudahan melakukan hubungan, komunikasi yang baik, perhatian pribadi dan memahami kebutuhan para pelanggan.

Pelayanan yang berkualitas menurut Valerie A. Zeithaml (dalam Rajawali View, 2003) adalah kemampuan suatu perusahaan menyajikan atau memenuhi apa yang dijanjikannya kepada pelanggan. Kualitas pelayanan yang baik sering dikatakan sebagai salah satu faktor penting dalam keberhasilan suatu bisnis. Penelitian yang dilakukan oleh Dabholkar, et. al. (2000) dalam Tjiptono (2005) menyatakan bahwa kualitas jasa mempunyai pengaruh yang signifikan terhadap kepuasan pelanggan. Maka, suatu perusahaan dituntut untuk memaksimalkan kualitas pelayanannya agar mampu menciptakan kepuasan para pelanggannya.

\section{Kepuasan Pelanggan}

56

Jurnal Komunikasi Bisnis dan Manajemen

Vol.7 No.2 Juli 2020 
Kepuasan pelanggan merupakan faktor terpenting dalam berbagai kegiatan bisnis. Kepuasan pelanggan adalah tanggapan konsumen terhadap evaluasi ketidaksesuaian yang dirasakan antara harapan yang sebelumnya dengan kinerja produk yang dirasakan. Dengan terpuaskannya keinginan dan kebutuhan para pelanggan, maka hal tersebut memiliki dampak yang positif bagi perusahaan. Apabila konsumen merasa puas akan suatu produk tentunya konsumen tersebut akan selalu menggunakan atau mengkonsumsi produk tersebut secara terus menerus. Dengan begitu produk dari perusahaan tersebut dinyatakan laku di pasaran, sehingga perusahaan akan dapat memperoleh laba dan akhirnya perusahaan akan tetap survive atau dapat bertahan bahkan kemungkinan akan berkembang.Menurut Gerso Ricard (2000:3) menyatakan bahwa Kepuasan pelanggan adalah "persepsi pelanggan bahwa harapannya telah terpenuhi atau terlampaui".

Kesimpulan yang dapat diambil dari definisi-definisi di atas adalah bahwa pada dasarnya pengertian kepuasan pelanggan mencakup perbedaan antara harapan dengan hasil dari kinerja yang dirasakan.

Agar dapat bertahan di dunia persaingan bisnis, maka perusahaan harus berusaha sekeras mungkin agar konsumen tidak pergi. Agar konsumen tidak pergi hendaknya perusahaan harus memenuhi kebutuhan dan kepuasan konsumen. Untuk mewujudkannya maka perusahaan harus melakukan empat hal yaitu sebagai berikut:

1) Mengidentifikasi mengenai siapa yang akan menjadi pelanggan

2) Memahami tingkat harapan pelanggan atas harga produk atau kualitas Produk

3) Memahami strategi kualitas produk yang dihasilkan untuk pelanggan

4) Memahami siklus pengukuran dan umpan balik dari kepuasan pelanggan.

\section{METODE PENELITIAN}

57

Jurnal Komunikasi Bisnis dan Manajemen

Vol.7 No.2 Juli 2020 
Penelitian ini adalah penelitian kuantitatif. Desain penelitiannya dengan prosedur penelitian formal yang berisi definisi yang jelas dari sasaran penelitian dan kebutuhan informasi. Untuk menjawab dan mencapai tujuan penelitian tersebut, maka akan digunakan analisis regresi. Analisis regresi adalah suatu metode statistika yang bertujuan untuk melihat arah hubungan dan besarnya pengaruh antar 2 atau lebih variabel dalam bentuk yang linear. Oleh karena itu, maka model penelitian dalam penelitian ini adalah $\mathbf{Y}=\boldsymbol{\alpha}+\boldsymbol{\beta} \mathbf{X}+\mathbf{e}$. Unit yang menjadi objek penelitian ini adalah pelanggan atau calon pelanggan Café Kupi Datu dengan intensitas pembelian minimal 1 (satu) kali.

Untuk memudahkan justifikasi terhadap persepsi konsumen digunakan skala Likert 5 poin. Skala Likert adalah skala yang digunakan dalam quesioner agar mempermudah responden dalam menjawab pertanyaan, kemudian responden menjawab pertanyaan sesuai dengan kode yang ada dalam quesioner. Jawaban dari para responden yang tercantum dalam quesioner bersifat tertutup dan dijamin kerahasiaannya

\section{HASIL PENELITIAN DAN PEMBAHASAN}

\section{Hasil Uji Validitas Dan Reliabilitas Instrumen Penelitian}

Langkah pertama dalam analisis ini adalah melakukan uji validitas dan reliabilitas instrument penelitian. Berdasarkan dari uji validitas menunjukkan bahwa nilai rhitung lebih besar dibanding nilai rtabel. Dengan hasil ini maka kuesioner yang digunakan oleh variabel harga (X1), promosi (X2) dan kualitas pelayanan (X3) dinyatakan valid sebagai alat ukur variabel.

\section{Hasil Uji Reliabilitas}


Berdasarakan hasil uji reliabilitas menunjukkan nilai cronbach's alpha variabel $\mathrm{X}$ di atas 0,60. Hal ini berarti kuesioner dari masing-masing indikator terbukti dapat dipercaya untuk digunakan sebagai alat ukur variabel.

Langkah selanjutnya adalah melakukan uji asumsi klasik, dengan urutan pengujian sebagai berikut:

\section{Uji Autokorelasi}

Konsekuensi dari adanya autokorelasi dalam suatu model regresi adalah varians sampel tidak dapat menggambarkan varians populasinya. Lebih lanjut lagi, model regresi yang dihasilkan tidak dapat digunakan untuk menaksir nilai variabel dependent pada nilai independent tertentu.

Berdasarkan hasil uji Autokorelasi menunjukan bahwa hasil analisis yang dilakukan koefisien Durbin-Watson sebesar 1.982, maka keputusannya bahwa dalam model Regresi tidak ada Autokorelasi.

\section{Uji Multikolinieritas}

Hasil uji Multikolinearitas menunjukkan nilai VIF dari masing-masing variabel bebas semuanya dibawah 5, maka penelitian ini bebas masalah multikolinearitas. Artinya berdasarkan hasil uji Multikolinearitas bahwa variabel Harga dan variabel Kualitas Pelayanan sama-sama memiliki nilai toleransi yaitu: 0,850 dengan VIF sebesar 1.176. Variabel Promosi memiliki nilai tolenransi sebesar 0,997 dengan nilai VIF sebesar 1.003. Dengan demikian, dapat disimpulkan bahwa variabel Harga, Promosi dan variabel Kualitas Pelayanan memiliki nilai VIF kurang dari 10 dan nilai tolerance diatas 0,1 maka dapat disimpulkan tidak terjadi multikolinieritas.

\section{Uji Regresi Linier Berganda}


Hasil uji regesi berganda variabel harga (X1), promosi (X2) dan kualitas pelayanan (X3) terhadap kepuasan konsumern dapat dilihat pada Tabel 1.

Tabel 1 Hasil Uji Regresi Linier Berganda

\begin{tabular}{|c|c|c|c|c|c|c|}
\hline \multicolumn{2}{|c|}{ Model } & \multirow{2}{*}{\multicolumn{2}{|c|}{$\begin{array}{l}\text { Unstandardized } \\
\text { Coefficients } \\
\begin{array}{c|c} & \text { Std. } \\
\text { B } & \text { Error }\end{array}\end{array}$}} & \multirow{2}{*}{$\begin{array}{c}\text { Standardiz } \\
\text { ed } \\
\text { Coefficient } \\
\text { s } \\
\text { Beta }\end{array}$} & \multirow[t]{2}{*}{$\mathrm{t}$} & \multirow[t]{2}{*}{ Sig. } \\
\hline & & & & & & \\
\hline \multirow[t]{4}{*}{1} & (Constant) & 1.554 & .802 & & 1.938 & .056 \\
\hline & Harga & .659 & .103 & .499 & 6.428 & .000 \\
\hline & Promosi & .127 & .163 & .056 & .782 & .044 \\
\hline & Kualitas Pelayanan & .526 & .119 & .345 & 4.439 & .000 \\
\hline
\end{tabular}

Sumber: Data diolah Tahun 2020.

Dari tabel diatas, maka persamaan Regresi yang terbentuk adalah $\mathrm{Y}=\mathbf{1 . 5 5 4}+\mathbf{0 , 6 5 9}$ $\mathrm{X} 1+0,127 \mathrm{X} 2+0,526 \mathrm{X} 3+$ e. Hasil dari analisis tersebut dapat diinterprestasikan sebagai berikut: $\mathrm{a}=1.554$, artinya bahwa apabila variabel Harga, Promosi dan Kualitas Pelayanan sama dengan nol maka kepuasan konsumen akan naik sebesar 1.554 satuan. b1=0.659, artinya bahwa apabila Café Kupi Datu memperhatikan variabel Harga (X1), maka kepuasan konsumen akan naik sebesar 0,659 satuan atau sebesar 65,9\% , sedangkan variabel lain konstan. b2=0.127, artinya bahwa apabila Café Kupi Datu memperhatikan variabel Promosi (X2), maka kepuasan konsumen akan naik sebesar 0.127 satuan atau sebesar $12,7 \%$, sedangkan variabel lain konstan. b3=0.526, artinya bahwa apabila Café Kupi Datu memperhatikan variabel Kualitas Pelayanan (X3), maka kepuasan konsumen akan naik sebesar 0,526 satuan atau sebesar 52,6\%, sedangkan variabel lain konstan.

\section{Tabel 2 Hasil Uji t}

\begin{tabular}{|l|c|c|c|c|}
\hline $\begin{array}{l}\text { Mode } \\
1\end{array}$ & $\begin{array}{c}\text { Unstandardized } \\
\text { Coefficients }\end{array}$ & $\begin{array}{c}\text { Standardiz } \\
\text { ed } \\
\text { Coefficient }\end{array}$ & $\mathrm{t}$ & Sig. \\
\hline
\end{tabular}

60

Jurnal Komunikasi Bisnis dan Manajemen

Vol.7 No.2 Juli 2020 


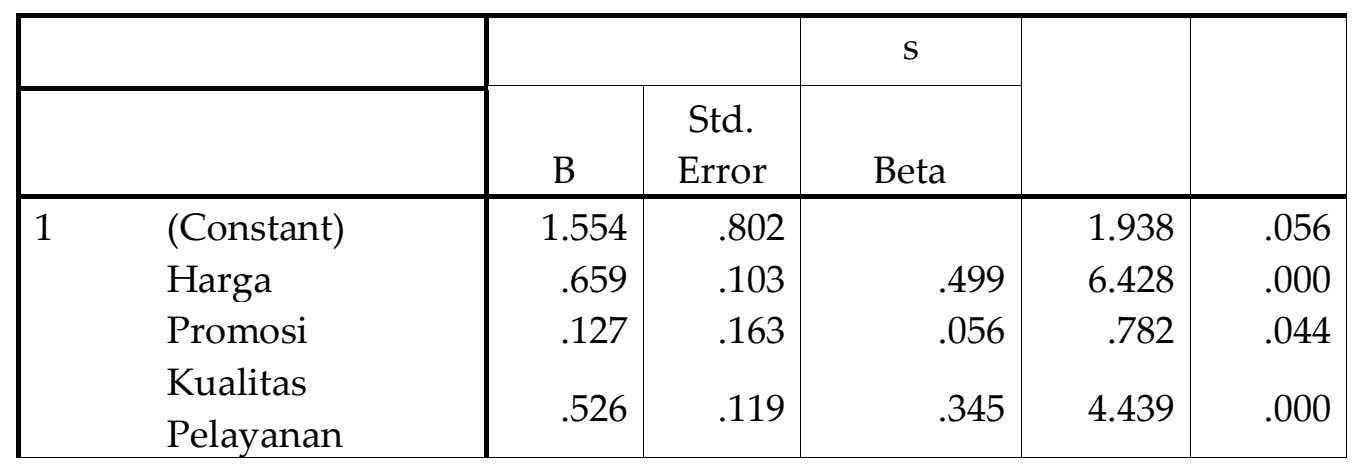

Sumber: Data diolah Tahun 2020.

Dari hasil uji $t$ pada tabel diatas terlihat bahwa, nilai signifikan $t$ untuk $X 1, X 2$ dan X3 yang masing-masing mempunyai nilai t signifikan $0.000,0.044$ dan 0.000 artinya signifikan dalam mempengaruhi kepuasan pelanggan/konsumen. Jadi $\mathrm{H}_{0}$ ditolak dan $\mathrm{H}_{\mathrm{a}}$ diterima.

\section{Pembahasan Hasil Penelitian}

Dari hasil analsis yang dilakukan, diperoleh bahwa Harga, Promosi dan Kualitas Pelayanan berpengaruh secara siginifikan dan perubahannya berubah searah dengan kepuasan pelanggan. Artinya jika tingkat Harga, Promosi dan Kualitas Pelayanan yang dirasakan makin tinggi, maka mengakibatkan makin tinggi juga kepuasan pelanggan atau konsumen Café Kupi Datu. Hasil pengolahan data penelitian ini, ternyata variabel bebas yang memiliki beta terbesar adalah variabel Harga (X1) yaitu sebesar 0,659 atau sebesar 65,9\%. Oleh karena itu dapat dikatakan bahwa variabel yang memiliki pengaruh terbesar terhadap kepuasan pelanggan Café Kupi Datu adalah variabel X1 (Harga) yaitu dengan koefisien regresi baku sebesar 0.659.

Hasil pembuktian hipotesa pertama (H1) yaitu keputusannya menolak $\mathrm{H}_{0}$ dan menerima $\mathrm{H}_{a}$ yang artinya uji $\mathrm{F}$ terhadap persamaan regresi yang diperoleh dari penelitian ini menunjukan hasil bahwa, secara bersama-sama ketiga variabel harga, promosi dan kualitas pelayanan berpengaruh terhadap pada kepuasan konsumen Café Kupi Datu. Implikasi hasil uji F bagi Café Kupi Datu jika mereka akan meningkatkan 
kepuasan konsumennya perlu menekankan pada tiga faktor tersebut yaitu berturutturut harga, promosi dan kepuasan konsumen. Hal ini harus dilakukan secara terus menerus (continues improvement) dalam usaha untuk persaingan (kompetisi) yang semakin ketat antar pengusaha café-café yang sejenis.

Untuk mengetahui seberapa besar tingkat kepuasan konsumen Café Kupi Datu terhadap setiap konsumen atau pelanggannya dapat kita lihat pada tabel sebagai berikut:

\section{Tabel 3 Tingkat Kepuasan Konsumen Café Kupi Datu}

\begin{tabular}{lcccccccccccc}
\hline & \multicolumn{11}{c}{ Skor*) } \\
\cline { 2 - 11 } & 1 & & 2 & & 3 & & 4 & & 5 & & Total \\
Variabel & $\sum$ & $\%$ & $\sum$ & $\%$ & $\sum$ & $\%$ & $\sum$ & $\%$ & $\sum$ & $\%$ & $\sum$ \\
Kepuasan & 3 & $3 \%$ & 9 & $9 \%$ & 30 & $30 \%$ & 47 & $47 \%$ & 11 & $11 \%$ & $100 \%$ \\
Konsumen & & & & & & & & & & & \\
\hline
\end{tabular}

Sumber: Data diolah (2020).

Keterangan: *) Skor jenjang penilaian responden dari 1s/d 5

Berdasarkan tabel di atas dapat ditarik kesimpulan, bahwa konsumen Café Kupi Datu yang merasa puas atas pelayanan adalah 47\% , Netral sebesar 30\% sedangkan yang menjawab sangat puas sebanyak 11\%, dan yang menyatakan tidak puas sebesar $9 \%$ dan responden yang menjawab sangat tidak puas sebesar $3 \%$.

Implikasi kondisi ini adalah mengingat pendekatan yang kita pergunakan untuk menilai tingkat kepuasan konsumen Café Kupi Datu User Based Approach, maka kualitas bagi seseorang (konsumen adalah sama dengan kepuasan maksimum yang dirasakannya, oleh karena konsumen Café Kupi Datu berada pada tingkat puas dan 
netral (cukup puas) yang bisa juga diartikan bahwa variabel harga, promosi dan kualitas pelayanan Café Kupi Datu masih berada pada taraf cukup baik oleh karena itu perlu dilakukan perbaikan-perbaikan ketiga variabel tersebut.

\section{KESIMPULAN}

Kualitas pelayanan Café Kupi Datu menurut persepsi konsumen baru pada tingkat cukup baik, oleh karena itu untuk meningkatkan daya saing dan mencapai tujuan profitabilitas, secara keseluruhan kualitas pelayanan Café Kupi Datu perlu ditingkatkan secara berkesinambungan (Continuous Improvement). Variabel dalam penelitian terhadap Café Kupi Datu yang paling mendesak untuk diperbaiki dan diperhatikan adalah harga, karena unsur harga inilah yang paling besar pengaruhnya terhadap kepuasan konsumen Café Kupi Datu, jika tidak maka pihak Café Kupi Datu akan mengalami penurunan jumlah pendapatan atau omset secara terus-menerus.

Untuk dapat meningkatkan kepuasan konsumen melalui variabel harga, manajemen Café Kupi Datu dapat melakukan usaha-usaha salah satunya kejelasan harga yang ditawarkan kepada konsumen.

\section{DAFTAR PUSTAKA}

Arikunto, Suharsimi., 2002, Prosedur Penelitian Suatu Pendekatan Praktek Edisi

Revisi V,Jakarta: Rineka Cipta.

Anogara, P. (2006). Psikologi Kerja. Jakarta: Rineka Cipta.

Agustyn, Renata Riskia. 2012. Analisis Pengaruh Kualitas Pelayanan Terhadap

Kepuasan Pelanggan (Studi Pada Pelanggan Kantor Pos Purworejo). Jurnal Universitas Diponegoro.

Basu Swastha dan Irawan. 2001. Manajemen Pemasaran Modern. Yogyakarta:

FE UGM.

63

Jurnal Komunikasi Bisnis dan Manajemen

Vol.7 No.2 Juli 2020 
Barnes, James G. 2006. Secret Customer Relationship Management. Yogyakarta : Andi.

Ferrinadewi, Erna, 2005, Atribut Produk Yang Dipertimbangkan dalam Pembelian Kosmetik dan Pengaruhnya pada Kepauasan Konsumen di Surabaya, Jurnal Manajemen dan Kewirausahawan, Volume Ketujuh, No. 2. September 2005.

Ghozali, Imam H (2007). Aplikasi Analisis Multivariate dengan Program SPSS. Cetakan keempat. Semarang : Badan Penerbit Universitas Diponegoro.

Irawan dan Basu Swastha. 2005. Manajemen Pemasaran Modern. Liberty. Yogyakarta.

Irawan, Prasetya (2006), Metode Penelitian Kualitatif dan Kuantitatif Ilmu - Ilmu Sosial, Jakarta.

Juwandi, Hendy Irawan. 2004. Kepuasan Pelayanan Jasa. Erlangga. Jakarta.

M. Kuncoro (2003). Metode Riset Untuk Bisnis dan Ekonomi. Jakarta : Erlangga.

Kotler, Philip. 2009. Manajemen Pemasaran. Jakarta : Erlangga

Lupiyoadi, Rambat dan Hamdani, A. 2001. Manajemen Pemasaran Jasa. Salemba Empat. Jakarta.

Sekaran, Uma (2000). Research Methods for Business. $3^{\text {rd }}$ ed. New York : John Wiley \& Sons.

Sofyan, Assauri, 2003. Usahawan Indonesia. Costomer Satisfaction. Januari.

Sumarwan, Ujang, 2003, Perilaku Konsumen: Konsep dan Implikasi untuk Strategi dan Penelitian Pemasaran, Penerbit Ghalia Indonesia, Jakarta.

Sudarmanto, R. Gunawan. (2005), Analisis Regresi Linier Ganda Dengan SPSS Edisi Pertama. Cetakan Pertama. Yogyakarta : Graha Ilmu.

Sekaran, U (2006). Metodologi Penelitian Untuk Bisnis. Edisi Kedua. Jakarta : Salemba Empat.

64

Jurnal Komunikasi Bisnis dan Manajemen Vol.7 No.2 Juli 2020 
